\title{
Peran Ibu sebagai Orang Tua Tunggal dalam Mendukung Pendidikan Anak di Masa Pandemi Covid-19
}

\section{The Role of Mothers as Single Parents in Supporting Children's Education During The Covid-19 Pandemic}

\author{
Fitri Qori Imami*, Yosafat Hermawan Trinugraha \& Abdul Rahman \\ Program Studi Pendidikan Sosiologi Antropologi, Fakultas Keguruan dan Ilmu Pendidikan, \\ Universitas Sebelas Maret, Indonesia
}

Diterima: 29 Mei 2021 Direview: 29 Mei 2021; Disetujui: 08 Agustus 2021 *Coresponding Email: yosafathermawan@staff.uns.ac.id

\begin{abstract}
Abstrak
Penelitian ini bertujuan untuk mengetahui dan menjelaskan peran ibu sebagai orang tua tunggal dalam memberikan dukungan pendidikan kepada anak di masa pandemi Covid-19. Teori yang digunakan dalam penelitian ini adalah teori fungsional struktural oleh Talcott Parsons. Metode penelitian ini adalah kualitatif dengan pendekatan studi kasus. Teknik pengumpulan data yang digunakan adalah wawancara, observasi, dan dokumentasi dengan triangulasi sumber untuk menguji keabsahan data. Analisis data menggunakan analisis data dari Miles dan Huberman. Hasil penelitian menunjukkan bahwa peran ibu sebagai orang tua tunggal dalam menjalankan fungsi pendidikan dapat berjalan dengan baik yaitu dengan memberikan dukungan pendidikan kepada anak khususnya di masa pandemi Covid-19, yaitu dengan menemani anak belajar, membantu belajar anak, mengingatkan anak untuk aktif mengikuti kelas dan mengerjakan tugasnya, memenuhi fasilitas belajar, dan selalu memberikan motivasi serta nasihat kepada anak. Berbagai kendala juga dialami oleh ibu tunggal, yaitu mereka tidak bisa mendampingi secara penuh dan langsung saat anak belajar dari rumah. Selain itu, ibu tunggal juga merasa kesulitan dalam memberikan dukungan kepada anak secara sendiri, karena anak terkadang sulit diatur. Hal itu terjadi karena tidak adanya sosok ayah di dalam keluarga.
\end{abstract}

Kata Kunci: Peran Ibu Tunggal; Kebutuhan Pendidikan Anak; Pandemi Covid-19

\begin{abstract}
This research aims to identify and explain the role of mothers as single parents in providing educational support to children during the Covid-19 pandemic. The theory used in this research is structural functional theory by Talcott Parsons. This research method is qualitative with a case study approach. Data collection techniques used were interviews, observation, and documentation with triangulation of sources to test the validity of the data. Data analysis used data analysis from Miles and Huberman. The results show that the role of mothers as single parents in carrying out educational functions can run well, namely by providing educational support to children, especially during the Covid-19 pandemic, namely by accompanying children to study, helping children learn, reminding children to actively participate in classes and do their duties, meet learning facilities, and always provide motivation and advice to children. Single mothers also experience various obstacles, namely that they cannot fully and directly accompany their children when learning from home. In addition, single mothers also find it difficult to provide support to their children on their own, because children are sometimes difficult to manage. This happened because there was no father figure in the family.
\end{abstract}

Keywords: Role of Single Mothers; Children's Educational Needs; Covid-19 Pandemic

How to Cite: Imami, F.Q., Trinugraha, Y.H., \& Rahman, A. (2021). Peran Ibu sebagai Orang Tua Tunggal dalam Mendukung Pendidikan Anak di Masa Pandemi Covid-19. Journal of Education, Humaniora, and Social Sciences (JEHSS), 4 (2): 793-800. 


\section{PENDAHULUAN}

Keluarga merupakan unit terkecil dalam masyarakat. Di dalam keluarga itulah seseorang akan mendapatkan pendidikan dan bimbingan pertama sebelum nantinya menghadapi kehidupan sosial yang lebih luas. Dengan adanya pendidikan di dalam keluarga nantinya akan memberikan pengaruh dan konstribusi yang besar bagi perkembangan anak. Dalam hal ini peran orang tua di dalam keluarga sangatlah penting terutama bagi pendidikan anak-anaknya. Menurut Bloom (W. Rahayu, 2011) menyatakan bahwa keterlibatan orang tua dalam mendidik anak menjadi penyebab kesuksesan belajar anak. Sehingga orang tua memiliki kewajiban untuk mendidik anak dan memberikan fasilitas yang sesuai dengan kebutuhan pendidikan anak.

Keluarga yang utuh di mana ada ayah, ibu, dan anak akan memberikan pengaruh yang baik bagi setiap anggota keluarga, khususnya bagi perkembangan anak. Namun, jika di dalam keluarga terdapat salah satu anggota keluarga yang hilang, maka sebuah keluarga akan mengalami kegoyahan dan menjadikan sebuah keluarga itu tidak utuh. Dalam masyarakat banyak ditemui sebuah keluarga yang tidak lengkap anggota keluarganya, seperti keluarga yang hanya ada orang tua tunggal atau biasa dikenal dengan istilah single parent. Keluarga single parent merupakan keluarga yang di dalamnya merujuk pada orang tua yang membesarkan satu atau lebih anak dan tidak tinggal bersama pasangan mereka (Nieuwenhuis \& Maldonado, 2018). Hal itu dapat terjadi sebagai akibat perceraian dan kematian. Dengan adanya perceraian maupun kematian akan membuat fungsi di dalam keluarga mengalami gangguan dan pihak yang mengalaminya harus menyesuaikan dengan situasi yang baru (Sunarto, 2004).

Berdasarkan data dari Dinas Kependudukan dan Pencatatan Sipil Kota Surakarta Tahun 2020 juga menunjukkan bahwa kasus perceraian perempuan itu lebih banyak daripada jumlah kasus perceraian laki-laki. Hal itu dapat dilihat pada tabel berikut ini.

Tabel 1. Jumlah Penduduk Kota Surakarta Berdasarkan Status Perkawinan

\begin{tabular}{lcc}
\hline $\begin{array}{c}\text { Status } \\
\text { Perkawinan }\end{array}$ & Pria & Wanita \\
\hline Cerai Mati & 7.566 & 28.850 \\
Cerai Hidup & 5.392 & 8.029 \\
\hline \multicolumn{1}{c}{ Jumlah } & 12.958 & 36.879 \\
\hline Sumber : Dispendukcapil Kota Surakarta Tahun 2020
\end{tabular}

Berdasarkan tabel tersebut dapat dikatakan bahwa jumlah perempuan yang berstatus orang tua tunggal banyak dijumpai di Kota Surakarta.

Dalam penelitian ini, peneliti akan memfokuskan pada ibu sebagai single parent atau orang tua tunggal. Ibu tunggal merupakan seorang wanita yang harus memikul tanggung jawab berat, di mana ia harus menyediakan sumber keuangan, mengurus rumah tangga, mendidik, dan merawat anak-anak (Ghani, Roeswardi, \& Aziz, 2014).

Dengan adanya pandemi Covid-19 ini membuat adanya berbagai perubahan di segala bidang, seperti pada pelaksanaan pendidikan yang sebelumnya dilaksanakan oleh lembaga pendidikan, namun sekarang dilaksanakan di dalam lembaga keluarga yang mana peran orang tua sangat diperlukan untuk mendampingi proses belajar anak di rumah dan memiliki peran besar dalam membantu pencegahan penyebaran virus Covid-19. Menurut Soekanto dan Sulistyowati (Sari \& Wisroni, 2020) bahwa hal itu tentunya juga menjadi tantangan sendiri bagi keluarga yang rentan mengalami disorganisasi, seperti anggota keluarga yang tidak lengkap, kurangnya komunikasi antaranggota, krisis keluarga, dan putusnya perkawinan orang tua.

Seperti pada keluarga single parent yang mana hanya ada satu orang tua saja, di mana seorang ibu sebagai orang tua tunggal tidak hanya dituntut untuk memenuhi kebutuhan keluarga, tetapi juga dituntut untuk memenuhi dan mendukung pendidikan anak selama proses belajar di rumah. Tentu hal itu akan membuat orang tua tunggal mengalami berbagai kesulitan, karena orang tua dituntut untuk mampu membimbing anak belajar dan mampu menggantikan guru di sekolah. Sehingga seorang ibu sebagai orang tua tunggal harus dapat menjalankan perannya dengan baik, 
karena peran orang tua menjadi aspek penting dalam keberhasilan pendidikan anak khususnya selama masa pandemi Covid-19.

Dengan adanya kegiatan belajar anak yang dilakukan dari rumah tentu akan menambah beban tanggung jawab khususnya bagi seorang ibu yang berstatus orang tua tunggal yang ada di Kampung Nayu Barat, Kelurahan Nusukan, Kecamatan Banjarsari, Kota Surakarta dan tentu hal itu tidaklah mudah. Mereka harus dapat membagi waktu antara bekerja dan mendampingi anak saat belajar di rumah. Dengan tidak adanya ayah sebagai kepala keluarga membuat mereka akhirnya menjalankan peran gandanya sebagai ibu dan ayah dari anak-anaknya.

Namun, semua peran yang dilakukan oleh ibu sebagai orang tua tunggal di Kampung Nayu Barat tidaklah mudah khususnya selama masa pandemi Covid-19 ini. Hal itu terjadi karena mereka semua harus bekerja di luar dengan risiko penularan. Berdasarkan berita yang ditulis oleh Budiman dari Tempo.co (2021) temuan KPAI bahwa belajar anak dari rumah kurang efektif karena kurangnya pengasuhan anak saat di rumah. Seperti anak yang hanya memiliki satu orang tua saja dan harus bekerja. Sehingga orang tua tidak bisa terlibat secara penuh dan langsung dalam kegiatan belajar anak selama di rumah.

Dalam kaitannya dengan penelitian yang membahas tentang peran ibu sebagai orang tua tunggal ini juga banyak dijelaskan oleh beberapa penelitian sebelumnya. Meskipun demikian, beberapa penelitian tentang peran orang tua tunggal tentu memiliki fokus penelitian yang berbeda. Seperti penelitian yang dilakukan oleh Hanim yang membahas tentang perempuan sebagai single parent dalam memenuhi fungsi ekonomi keluarganya. Hasil penelitiannya menjelaskan bahwa perempuan single parent mempunyai peranan utama sebagai kepala rumah tangga sekaligus pencari nafkah utama bagi keluarga dan anak-anaknya (Hanim, 2018).

Penelitian lain yang membahas tentang orang tua tunggal juga dilakukan oleh Rahayu. Dalam penelitian Rahayu membahas tentang bentuk kehidupan sosial ekonomi single mother dalam ranah domestik dan publik. Hasil penelitiannya menunjukkan bahwa bentuk dan peran sosial yang ditunjukkan oleh seorang single mother, yaitu hidup dengan orang tua mereka untuk menghindari tekanan sosial, melibatkan orang tua mereka dalam merawat anak, dan berpatisipasi dalam berbagai kegiatan di masyarakat. Sedangkan bentuk dan peran adaptasi ekonomi oleh seorang single mother terlihat dalam penyelarasan jumlah pendapatan dan kebutuhan keluarga setiap hari (A. Rahayu, 2017).

Penelitian yang dilakukan oleh Nurdiana, Rachman, dan Pramono juga membahas tentang peran ibu sebagai orang tua tunggal yang berfokus dalam mengembangkan moralitas anak di Kelurahan Tlogo Mulyo, Semarang. Hasil penelitiannya menunjukkan bahwa meskipun menjadi ibu tunggal yang memiliki banyak kesibukan dalam mencari nafkah, tetapi ibu tunggal bisa membagi waktunya dalam membimbing, memantau, dan mengarahkan tumbuh kembang anak. Ibu tunggal mampu menanamkan pengetahuan moral, perasaan moral, dan mewujudkan tindakan moral bagi anak-anaknya (Nurdiana, Rachman, \& Pramono, 2017).

Berdasarkan penelitian yang sudah dilakukan sebelumnya oleh Hanim, Rahayu, dan Nurdiana dkk memiliki kesamaan dalam membahas tentang peran ibu sebagai orang tua tunggal. Maka dalam penelitian ini, peneliti membuat fokus penelitian yang berbeda dari penelitian sebelumnya. Dalam penelitian ini peneliti akan membahas mengenai peran ibu sebagai orang tua tunggal dalam mendukung pendidikan anak pada masa pandemi Covid-19. Dari beberapa penelitian sejenis tentang orang tua tunggal, masih belum banyak yang membahas tentang pemberian dukungan pendidikan ke anak yang dilakukan oleh ibu sebagai orang tua tunggal, terlebih pada masa pandemi Covid-19 ini, yang mana merupakan fenomena baru yang sedang terjadi dan perlu dikaji.

Berdasarkan uraian di atas, penelitian ini bertujuan untuk mengetahui dan menjelaskan peran ibu sebagai orang tua tunggal dalam mendukung pendidikan anak selama masa pandemi Covid-19 dan kendala yang dihadapi oleh seorang ibu sebagai orang tua tunggal dalam memberikan dukungan pendidikan anak selama masa pandemi Covid-19. 


\section{METODE PENELITIAN}

Penelitian ini menggunakan metode kualitatif deskriptif dengan pendekatan studi kasus. Fokus pada penelitian ini, yaitu terkait peran yang dilakukan oleh ibu sebagai orang tua tunggal dalam mendukung pendidikan anak di rumah selama masa pandemi Covid-19 di Kampung Nayu Barat, Kelurahan Nusukan, Kecamatan Banjarsari, Kota Surakarta.

Teknik pengumpulan data yang digunakan dalam penelitian ini adalah wawancara, observasi, dan dokumentasi. Informan dalam penelitian ini dipilih menggunakan teknik purposive sampling berdasarkan kriteria, yaitu : (1) seorang perempuan yang berstatus sebagai janda atau single parent karena bercerai, baik itu cerai mati maupun cerai hidup (2) memiliki pekerjaan (3) mempunyai anak yang sedang bersekolah dan berusia 6-18 tahun.

Untuk menguji keabsahan data digunakan teknik triangulasi sumber, yaitu dengan membandingkan hasil wawancara yang sudah didapatkan dari informan utama dengan informan pendukung agar mendapatkan data yang valid. Analisis data dalam penelitian ini menggunakan analisis data dari Miles dan Huberman, yaitu pengumpulan data, reduksi data, penyajian data, penarikan simpulan dan verifikasi.

\section{HASIL DAN PEMBAHASAN}

Pada umumnya keluarga merupakan unit terkecil dalam masyarakat yang terdiri dari ayah, ibu, dan anak. Bentuk hubungan yang ada dalam keluarga lebih bersifat gemeinscaft dan merupakan ciri kelompok primer, di mana memiliki hubungan yang lebih intim, kooperatif, dan masing-masing anggota memperlakukan anggota yang lain sebagai tujuan (Khairuddin, 2008).

Menjadi orang tua tunggal tidaklah mudah, khususnya ketika seorang ibu yang menjadi orang tua tunggal bagi anak-anaknya. Terlebih lagi di masa pandemi Covid-19 yang kemudian membuat beban yang harus ditanggung oleh orang tua tunggal akan bertambah khususnya dalam menjalankan fungsi pendidikan bagi anak, di mana harus memberikan waktu untuk memerhatikan anak dalam melakukan kegiatan belajar dari rumah.

Tentu hal itu dirasa sulit oleh para ibu tunggal yang ada di Kampung Nayu Barat, Kelurahan Nusukan, Kecamatan Banjarsari, Kota Surakarta. Mereka rata-rata bekerja dari pagi hingga sore sehingga perlu membagi waktu antara bekerja, mengurus anak, dan mengurus rumah. Hal itu juga dibuktikan oleh Hallberg and Klevmarken (Wang \& Xu, 2020) bahwa orang tua tunggal yang menjadi satu-satunya pengasuh anak akan membutuhkan waktu yang lebih banyak untuk memberikan tanggung jawab kepada anak.

Pada dasarnya pendidikan yang dilakukan di sekolah itu sangat penting bagi anak, karena menurut para ibu tunggal pendidikan itu sangat penting bagi masa depan anak supaya anak mendapat wawasan ilmu yang banyak dan dapat sukses kedepannya.

Namun, dengan adanya pandemi Covid-19 ini membuat beberapa orang tua tunggal mengeluhkan kegiatan belajar yang dilakukan dari rumah. Berbagai respon dari ibu tunggal terkait pelaksanaan kegiatan belajar dari rumah pun beraneka ragam. Para ibu tunggal merasa bahwa dengan bergantinya kegiatan belajar yang sebelumnya dilakukan di sekolah dan diganti di rumah membuat mereka kurang setuju dan merasa kesulitan, karena harapannya saat anak melakukan kegiatan belajar di rumah, orang tua dituntut agar dapat mendampingi dan berperan sebagai guru di rumah. Namun, hal itu tampaknya kesulitan jika harus dilakukan oleh orang tua tunggal.

Berdasarkan hasil wawancara dan observasi dengan 6 ibu yang berstatus orang tua tunggal juga didapati bahwa 5 diantaranya bekerja dari pagi hingga sore, dan 1 bekerja mulai dari sore hingga malam. Sehingga waktu yang mereka berikan kepada anak dalam hal pendampingan belajar dirasa masih kurang. Saat ibu tunggal yang belum berangkat kerja pun mereka hanya sesekali dalam memerhatikan anak belajar karena mereka juga harus menyelesaikan urusan rumah tangga sebelum berangkat bekerja. Hal itu juga membuat beberapa ibu tunggal merasa bersalah karena seharusnya orang tua dapat menemani anak saat belajar dari rumah secara penuh tetapi pada kenyataannya belum bisa memenuhi peran dan tanggung jawab tersebut sehingga anakpun merasa kurang perhatian dan kadang sulit untuk diatur.

Walaupun para ibu tunggal merasa kesulitan dan tidak bisa secara penuh mengawasi anak saat kegiatan belajar dari rumah, tetapi ada dari mereka yang tetap dapat meluangkan waktunya 
agar anak tetap mendapat perhatian dan pengawasan dari ibunya saat bekerja. Hal tersebut sejalan dengan pendapat Kholil (Cahyati \& Kusumah, 2020) bahwa orang tua mendampingi anak belajar di rumah sembari mengerjakan pekerjaannya menjadi tantangan tersendiri.

Pendidikan merupakan salah satu hal yang sangat penting yang harus ditanamkan pada anak-anak dan hal itu sudah menjadi tugas orang tua untuk memenuhi pendidikan anak-anaknya. Tak terkecuali bagi orang tua tunggal. Walaupun berada dalam keluarga yang tidak utuh tetapi hal itu tetap membuat para orang tua tunggal berjuang karena mereka memiliki harapan yang sama terhadap anak-anaknya, yaitu agar sukses dan menjadi kebanggaan keluarga.

Para ibu tunggal selalu menanamkan dan mengajarkan nilai-nilai kehidupan kepada anakanak mereka. Nilai agama yang sering ditanamkan oleh para ibu tunggal. Dengan harapan mereka dapat berperilaku sesuai dengan ajaran agama yang dianutnya. Selain itu, ibu tunggal juga mengajarkan pendidikan tentang sopan santun, tata krama, dan saling membantu antarsesama. Hal itu diajarkan kepada anak agar anak memiliki kepribadian yang baik dan mendapat pandangan yang baik dari masyarakat walaupun anak mereka hanya memiliki orang tua tunggal.

Pada masa pandemi ini kegiatan belajar dilakukan di rumah dan menuntut adanya peran orang tua untuk lebih memerhatikan anak, yaitu dengan cara sering mengajak anak berkomunikasi dan berusaha untuk memenuhi kebutuhan yang diperlukan oleh si anak dari segi fisik, rasa aman, kasih sayang. Hal itu dilakukan untuk memastikan bahwa mereka memiliki rasa percaya diri untuk beradaptasi dengan teman dan lingkungan masyarakat (Ghani et al., 2014).

Berbagai dukungan pun diberikan oleh para ibu tunggal kepada anak saat menjalani proses kegiatan belajar selama di rumah, yaitu dengan mengajak anak belajar bersama dan membantu anak saat mengalami kesulitan dalam mengerjakan tugas sekolahnya. Khususnya ibu tunggal yang memiliki anak usia sekolah dasar sehingga masih memerlukan pengawasan, karena jika tidak didampingi mereka tidak akan menyelesaikannya dan justru melakukan pekerjaan lainnya.

Para ibu tunggal juga selalu mengingatkan anak untuk mengikuti setiap kelas onlinenya, meminta anak untuk memerhatikan pelajaran yang disampaikan oleh guru, dan selalu mengingatkan anak untuk mengerjakan tugas-tugas yang diberikan oleh guru. Seperti yang diungkapkan oleh PJ pada salah satu wawancara berikut:

"Tak tanyai udah absen belum, pelajarannya apa, udah dikerjain belum tugase gitu mbak itu pasti mbak. Kadang yo ada tetangga yang ngingetke anaknya buat sekolah online gitu suruh absen."

Selain menemani, membantu mengerjakan tugas, dan mengingatkan anak dalam belajar, seorang ibu yang menjadi orang tua tunggal juga berusaha untuk memenuhi segala kebutuhan sekolah yang diperlukan anak saat kegiatan belajar di rumah. Sebagai ibu yang menjadi orang tua tunggal berupaya agar anak-anak tetap mendapatkan fasilitas sekolah saat belajar di rumah.

Berbagai fasilitas yang diperlukan dan harus dipenuhi anak saat kegiatan belajar di rumah, yaitu kuota internet. Saat pertama kali kegiatan belajar dari rumah dimulai, semua orang tua harus memenuhi kuota internet anak agar dapat mengakses belajar dari rumah. Sehingga hal itu juga membuat para ibu tunggal merasa keberatan karena harus membeli kuota internet yang tentu tidak murah. Namun, sekarang dengan adanya bantuan kuota internet dari pemerintah, para orang tua khususnya orang tua yang berstatus orang tua tunggal menjadi dimudahkan karena tidak perlu membelikan kuota internet yang terlalu banyak kepada anaknya.

Selain kuota internet, kebutuhan pendidikan yang harus dipenuhi, yaitu buku tulis, alat tulis, buku panduan, laptop, dan handphone. Di mana semua itu tentu masih diperlukan oleh anak walaupun kegiatan belajar sekolah dilakukan di rumah.

Berdasarkan hasil penelitian bahwa semua ibu yang berstatus orang tua tunggal memiliki harapan yang tinggi untuk pendidikan anak-anaknya. Hal itu sejalan dengan pendapat (Chan \& Li, 2020) bahwa:

"Expectation for school success andvalue of schooling are shaped by both parental expectation and child characteristics. As children's primary socializing agent, parents transmit their expectation and value to their children, which in turn influences children's self-efficacy and academic achievement." 
Para ibu tunggal menaruh harapan yang besar kepada anak-anak agar mereka tetap bisa sukses dalam pendidikannya walaupun tidak ada sosok ayah di dalam keluarganya.

Dukungan lain yang diberikan oleh seorang ibu tunggal untuk pendidikan anak, yaitu berupa motivasi dan pemberian nasihat. Hal itu sangat perlu dilakukan oleh ibu tunggal, karena saat anak sekolah di rumah kurang mendapat perhatian dari orang tua. Berbeda dengan orang tua yang selalu ada di rumah, anak-anak akan mendapat pengawasan dan perhatian lebih dari kedua orang tuanya.

Motivasi yang dilakukan oleh para ibu tunggal biasanya dalam bentuk nasihat, seperti selalu mengajak bicara anak dan sering bertanya terkait hal-hal yang berkaitan dengan sekolahnya. Para ibu tunggal memotivasi anaknya agar bisa memiliki tanggung jawab secara mandiri saat ibu tidak bisa mendampingi secara langsung anak dalam kegiatan belajar dari rumah. Seperti yang diungkapkan oleh DW berikut:

"Kalau saya sering ngobrol gitu ya mbak jadi banyak tanya kayak tugase apa, sudah selesai belum. Kalau memotivasinya ya dia kan udah kelas 3 juga jadi selalu tak bilangin kalau saat ini sudah menjadi tanggung jawab dia untuk menyelesaikan sekolah. Memang saya gak bisa mengawasi sepenuhnya, jadi kelas 3 harus serius, terus yo tak suruh aktif cari informasi perguruan tinggi juga. Kadang yo tak oyak-oyak itu mbak setiap hari."

Saat anak mendapat prestasi di sekolah pun ibu tunggal juga memberikan hadiah sebagai bentuk penghargaan. Anak berprestasi merupakan suatu hal yang membanggakan bagi semua orang tua, khususnya bagi orang tua tunggal. Selain itu, ibu tunggal juga memberi kebebasan dan mendukung anak untuk mengikuti berbagai kegiatan yang ada di sekolah maupun di masyarakat. Hal itu dilakukan oleh para ibu tunggal untuk mengembangkan pribadi anak agar anak dapat beradaptasi, diterima, berinteraksi, dan berkompetisi di dalam masyarakat lingkungan sosialnya (Samsudin, 2017).

Dalam kegiatan belajar selama di rumah tentu tidak selalu berjalan efektif. Hal itu terjadi karena saat anak belajar di rumah, para ibu tunggal tidak bisa selalu mengawasi dan memberikan perhatian kepada anak. Para ibu tunggal merasa waktu yang diberikan kepada anak masih kurang, karena mereka juga harus bekerja, sehingga untuk mengawasi anak belajar di rumah belum sepenuhnya bisa dilakukan dan hanya bisa dilakukan saat ibu tunggal sudah selesai bekerja.

Masalah dengan si anak sendiri pun juga dikeluhkan oleh para ibu tunggal, di mana anak mendapatkan tugas yang banyak. Apalagi ibu tunggal yang masih memiliki anak usia sekolah dasar yang harus membantu mengerjakan tugas setiap hari dan mengumpulkannya ke guru. Anak usia sekolah dasar tentu masih sangat perlu bimbingan dari orang tua, sehingga tak jarang para ibu tunggal mengeluhkan tugas yang begitu banyak dan merasa kesulitan saat memahami materi pelajaran anak.

Para ibu tunggal pun merasa bahwa anak mengalami perubahan saat belajar dari rumah, di mana anak menjadi malas, sering mengeluh, cepat bosan, kurang bersosialisasi, dan sering bergantung pada ibunya. Seperti yang diungkapkan oleh NS pada salah satu wawancara berikut:

"Agak susah ndidik anak gitu mbak, soale kan apa-apa sama mamahe jadi gak ada yang ditakuti. Beda kalau ada sosok ayah to mbak, yen mamahe kadang kan lembek, jadi bocahe agak mbangkang, soale sama om, keponakan saya ini yo gak takut mbak, takute yo sama mamahe tapi kan nek ibu beda yo mbak, jadi anake agak keras."

Para ibu tunggal mengeluhkan anaknya yang terkadang sulit untuk diatur dan dinasihati. Hal itu terjadi karena tidak adanya sosok ayah yang biasanya ditakuti oleh anak karena sikapnya yang tegas. Sedangkan ibu berbeda, karena ibu akan bersikap lebih halus kepada anak dan hal itu yang membuat anak terkadang tidak merasa takut dan cenderung menyepelekan.

Penelitian ini didukung dengan adanya teori Fungsional Struktural dari Talcott Parsons. Dalam teori ini, masyarakat dipandang sebagai suatu sistem sosial yang terdiri dari beberapa unsur yang saling berkaitan satu sama lain. Setiap aktor individu terlibat dalam hubungan interaktif dengan yang lainnya. Sehingga partisipasi dari seorang aktor di dalam hubungan interaktif keluarga merupakan unsur penting dari sistem sosial (Parsons, 1951). Berkaitan dengan penelitian ini, teori ini menekankan pada pembagian peran dan fungsi dalam keluarga, di mana setiap anggota keluarga memiliki tanggung jawab dalam melakukan tugasnya. Namun, jika ada 7क्gि http://mahesainstitute.web.id/ojs2/index.php/jehss 
anggota keluarga yang tidak dapat menjalankan peran dengan baik, atau ada anggota keluarga yang hilang, maka sistem di dalam keluarga tersebut akan terganggu. Hal tersebut terjadi karena hubungan antar peran dan fungsi antaranggota keluarga saling berkaitan. Parsons melihat bahwa suatu masyarakat untuk dapat bertahan harus menjalankan empat fungsi yang diperlukan oleh seluruh sistem, yaitu Adaptation, Goal, Integration, dan Latency (Ritzer \& Goodman, 2017).

Berdasarkan hasil penelitian yang dapat dikaitkan dengan konsep AGIL, seorang ibu tunggal tentu mengalami proses Adaptation (Adaptasi) karena harus menjadi orang tua tunggal yang berjuang sendirian dalam mengurus keluarga khususnya pada masa pandemi Covid-19. Para ibu tunggal menyadari bahwa sekarang ini peran mereka tidak hanya sebagai orang tua tetapi juga sebagai guru pengganti saat anak belajar di rumah. Hal itu membuat ibu tunggal mulai menyesuaikan dengan keadaan, di mana baik sebelum bekerja, saat bekerja, maupun setelah pulang bekerja selalu berusaha untuk memantau dan memenuhi segala kebutuhan untuk kegiatan belajar anak di rumah.

Seorang ibu sebagai orang tua tunggal juga berharap anak-anak mereka tetap merasakan jika mereka mendapat perhatian dari orang tua selama melakukan kegiatan belajar di rumah, meskipun ibu tunggal juga tidak selalu mendampingi anak karena harus mengurus pekerjaan lainnya. Mereka memiliki harapan agar pendidikan anak di rumah tetap terpenuhi selama pandemi ini.

Pencapaian Goal (Tujuan) yang dilakukan oleh ibu tunggal sudah tercermin dalam proses adaptasi. Berbagai upaya dilakukan oleh para ibu tunggal agar kegiatan belajar anak di rumah tetap berjalan dengan baik, yaitu menyempatkan waktu untuk memberikan perhatian dengan sering bertanya kepada anak, memenuhi kebutuhan belajar anak, dan membantu saat berlangsungnya kegiatan belajar anak di rumah khususnya bagi para ibu tunggal yang masih memiliki anak usia sekolah dasar. Para ibu tunggal juga meminta kepada anak-anak agar mereka tetap fokus saat proses belajar di rumah, walaupun ibu tunggal tidak sepenuhnya bisa mengawasi anak saat di rumah.

Proses Integration (Integrasi) dalam hal ini berperan dalam pemberian dukungan pendidikan kepada anak di tengah kesibukan bekerja dan mengurus rumah tangga. Para ibu tunggal berusaha untuk membagi waktu antara bekerja, mengurus rumah, dan mengurus anak. Seorang ibu tunggal di sini merupakan satu-satunya orang tua yang berkewajiban dalam mendampingi dan memerhatikan kondisi anak saat melakukan kegiatan belajar di rumah. Tanpa adanya peran ibu tunggal secara langsung dalam kegiatan belajar anak dari rumah akan membuat anak merasa kurang perhatian. Berdasarkan hasil penelitian, anak-anak yang ditinggal di rumah saat tidak diawasi oleh ibu tunggal cenderung melakukan aktivitas lainnya dan kurang memerhatikan pelajaran di sekolahnya. Sehingga kehadiran dan dukungan dalam hal perhatian dan motivasi dari ibu tunggal secara langsung sangat berpengaruh pada proses kegiatan belajar anak selama di rumah.

Latency (Pemeliharaan) yang dilakukan oleh seorang ibu tunggal agar anak tetap semangat dalam mengikuti kegiatan belajar dari rumah, yaitu selalu berkomunikasi dan memberikan dukungan salah satunya dengan memotivasi maupun menasihatinya agar mereka dapat melakukan kegiatan belajar dari rumah dengan baik meskipun ibu tunggal tidak sepenuhnya mendampingi anak selama di rumah. Dengan begitu pemeliharaan yang dilakukan oleh orang tua tunggal diharapkan proses pendidikan anak selama di rumah dapat berjalan dengan baik.

\section{SIMPULAN}

Seorang ibu tunggal di masa pandemi Covid-19 dalam menjalankan perannya mulai beradaptasi yang mana selain bekerja juga harus memerhatikan dan memenuhi kebutuhan pendidikan anak selama melakukan kegiatan belajar dari rumah. Keberjalanan fungsi pendidikan yang dilakukan oleh para ibu tunggal dapat berjalan dengan baik yaitu dengan memberikan dukungan seperti menemani dan membantu belajar si anak, mengingatkan anak untuk aktif mengikuti kelas dan mengerjakan tugasnya, memenuhi fasilitas belajar, dan selalu memberikan motivasi serta nasihat kepada anak. Ibu tunggal berusaha agar anak-anak mereka mendapatkan 
pendidikan yang baik dan nantinya bisa sukses. Berbagai kendala juga dialami oleh ibu tunggal di mana mereka tidak bisa mendampingi secara penuh dan langsung saat anak belajar dari rumah. Selain itu, ibu tunggal juga merasa kesulitan dalam memberikan dukungan kepada anak secara sendiri, karena anak terkadang sulit diatur. Hal itu terjadi karena tidak adanya sosok ayah di dalam keluarga.

\section{DAFTAR PUSTAKA}

Budiman, A. (2021). KPAI Temukan Pengasuhan Anak yang Bermasalah Hambat PJJ. Retrieved from https://nasional.tempo.co/read/1436763/kpai-temukan-pengasuhan-anak-yang-bermasalahhambat-pjj

Cahyati, N., \& Kusumah, R. (2020). Peran Orang Tua Dalam Menerapkan Pembelajaran di Rumah Saat Pandemi Covid 19. Jurnal Golden Age, 4(1), 152-159. https://doi.org/10.29408/jga.v4i01.2203

Chan, Y. Y., \& Li, J. Bin. (2020). An early look at parental expectation towards early childhood education among Pakistani parents in Hong Kong: The role of culture and acculturation. Children and Youth Services Review, 119, 105652. https://doi.org/10.1016/j.childyouth.2020.105652

Dispendukcapil Kota Surakarta. (2020). Buku Agregat Kependudukan Semester 1 Tahun 2020. Retrieved from https://dispendukcapil.surakarta.go.id/

Ghani, F. B. A., Roeswardi, S. I. bt, \& Aziz, A. bt A. (2014). Parenting Styles and their Relation to Teenagers' Personality Profile in Single Mother Families: A Case Study. Procedia Social and Behavioral Sciences, 114, 766-770. https://doi.org/10.1016/j.sbspro.2013.12.782

Hanim, H. (2018). Peran Perempuan Single Parent Dalam Pemenuhan Fungsi Ekonomi Dalam Keluarga Studi Kasus : Perempuan Single Parent Pekerja di Pijat Refleksi Tosyma Jakarta Selatan. Jurnal Ilmu Dan Budaya, 41(60), 7081-7100.

Khairuddin. (2008). Sosiologi Keluarga. Yogyakarta: Liberty.

Nieuwenhuis, R., \& Maldonado, L. C. (2018). The triple bind of single-parent families: Resources, employment and policies to improve wellbeing. Bristol: Policy Press.

Nurdiana, Rachman, M., \& Pramono, S. E. (2017). Peran Orang Tua Tunggal (Ibu) dalam Mengembangkan Moralitas Anak di Kelurahan Tlogo Mulyo Kecamatan Pedurungan Semarang. Journal of Educational Social Studies, 6(1), 52-58. https://doi.org/10.47647/jsr.v9i1.45

Parsons, T. (1951). The Social System. New York: Free Press.

Rahayu, A. (2017). Kehidupan Sosial Ekonomi Single Mother dalam Ranah Domestik dan Publik. Jurnal Analisa Sosiologi, 6(1), 82-99.

Rahayu, W. (2011). Analisis Intensitas Pendidikan oleh Orang Tua dalam Kegiatan Belajar Anak, Status Sosial Ekonomi Orang Tua terhadap Motivasi Belajar dan Prestasi Belajar Siswa. Jurnal Pendidikan Dan Pembelajaran (JPP), 18(1), 72-80.

Ritzer, G., \& Goodman, D. J. (2017). Teori Sosiologi Dari Teori Sosiologi Klasik Sampai Perkembangan Mutakhir Teori Sosial Postmodern. Bantul: Kreasi Wacana.

Samsudin, D. (2017). Sosiologi Keluarga: Studi Perubahan Fungsi Keluarga. Yogyakarta: Pustaka Belajar.

Sari, N. Y., \& Wisroni, W. (2020). The Urgency of Parental Guidance for Youth Education in the Belajar Dari Rumah (BDR) Era. SPEKTRUM: Jurnal Pendidikan Luar Sekolah (PLS), 8(3), 309. https://doi.org/10.24036/spektrumpls.v8i3.109565

Sunarto, K. (2004). Pengantar Sosiologi. Jakarta: Lembaga Penerbit Fakultas Ekonomi Universitas Indonesia.

Wang, S., \& Xu, Y. (2020). Transit use for single-parent households: Evidence from Maryland. Transportation Research Interdisciplinary Perspectives, 8. https://doi.org/10.1016/j.trip.2020.100223 